\title{
TOMBUL FINDIK ÇEŞİDİNDE YAĞ OKSİDASYONUNU AZALTACAK KURUTMA YÖNTEMİNİN BELİRLENMESİ
}

\author{
Ali Turan ${ }^{1 *}$ Ali İslam ${ }^{2}$ \\ ${ }^{1}$ Giresun Üniversitesi, Teknik Bilimler Meslek Yüksekokulu, Fındık Eksperliği Programı, Giresun \\ ${ }^{2}$ Ordu Üniversitesi, Ziraat Fakültesi, Bahçe Bitkileri Bölümü, Ordu, Türkiye
}

Geliş / Received: 11.02.2019; Kabul / Accepted: 13.06.2019; Online bask1 / Published online: 02.07.2019

Turan, A., İslam, A. (2019). Tombul findık çeşidinde yağ oksidasyonunu azaltacak kurutma yönteminin belirlenmesi. GID $A$ (2019) 44 (4): 563-575 doi:10.15237/gida.GD19040

Turan, A., Islam, A. (2019). Determination of drying method for reducing oil oxidation of Tombul (CV) bazelnut. GIDA (2019) 44 (4): $563-575$ doi:10.15237/gida.GD190402

ÖZ

Bu çalışma güneşte kurutma (beton harman ve çimen harman; $\mathrm{BH}, \mathrm{C \zeta H}$, sırasılla) ve suni kurutma (SK) yöntemlerinin depolama süresince findığın kimyasal özellikleri üzerine etkisini belirlemek amacıyla yürütülmüştür. Protein oranı, yağ oranı, nem oranı, su aktivitesi, aflatoksin, yağ asitleri kompozisyonu, toplam yağ asitleri ve yağ oksidasyon parametreleri 2014-2016 ylları arasında 18 ay ortam şartlarında (20$25^{\circ} \mathrm{C}$ ve $\% 70-90$ nisbi nem) muhafaza süresince incelenmiştir. Çalışma sonucunda tekli doymamış yă asitleri (TDY) ana grubu oluşturmuş (\%81.36-84.46), onu çoklu doymamış yağ asitleri (\%9.41-12.18) ve doymuş yağ asitleri (\%5.74-7.31) izlemiştir. SK ortamında güneşte kurutmaya göre daha yüksek TDY (\%84.46) tespit edilmiştir. Ayrıca SK ortamında daha düşük iyot değeri ve daha yüksek oleik/linoleik değeri bulunmuştur. Bu yüzden SK "Tombul” findık çeşidinin kurutulması için yeni bir potansiyel olabilir.

Anahtar kelimeler: Depolama, kurutma, yağ asitleri kompozisyonu, yağ oksidasyonu

\section{DETERMINATION OF DRYING METHOD FOR REDUCING OIL OXIDATION OF TOMBUL (CV) HAZELNUT}

\begin{abstract}
This work was carried out to evaluate the effects of sun-dried (concrete ground and grass ground; CG, GG, respectively) and artificial dried (DM) on chemical properties of hazelnut during storage. The following parameters were measured; protein, lipid and moisture content, water activity, aflatoxin, fatty acid composition, total fatty acids, and oil oxidation along 18 months storage (20142016) at $20-25{ }^{\circ} \mathrm{C}$ and $70-90 \%$ relative humidity. The results showed that monounsaturated fatty acid (MUFA) was the main fatty acid group (81.36-84.46\%) followed by polyunsaturated $(9.41-$ $12.18 \%$ ) and saturated fatty acids (5.74-7.31\%). Samples dried in DM had more MUFA $(84.46 \%)$ than those sun-dried samples. Furthermore, the lowest iodine value and the highest oleic/linoleic acidity ratio were found in DM. Hence, DM could be as the new potential for Tombul (cv) hazelnut drying.
\end{abstract}

Keywords: Storage, drying, fatty acid composition, oil oxidation

\footnotetext{
*Yazışmalardan sorumlu yazar / Corresponding author;

$\triangle$ ali.turan@giresun.edu.tr, $\quad$ (O) 4543103005 


\section{GİRİ̧̧}

Findık dünya pazarlarında satılan en önemli sert kabuklu meyve türlerinden biridir ve şu anda Türkiye findık üretim ve ticaretinin en fazla yapıldığ1 ülke durumundadır (Turan, 2018a). Ancak günümüze kadar findıkta modern tekniklerin yaygınlaştırılması konusunda ülkemiz maalesef mesafe alamamıştır. Özellikle meyve kalitesini en fazla etkileyen hasat sonras1 yöntemlerinden biri olan kurutma geleneksel olarak güneş altında beton ve çimen zemin üzerinde gerçekleştirilmektedir (Turan ve İslam, 2018). Bu yüzden de findıklar kurutma ve muhafaza süresince yağ oksidasyonuna maruz kalmaktadır (Turan, 2018b).

Bilindiği gibi kurutma, tarımsal ürünlerde en eski muhafaza yöntemlerinden birisidir (Kaveh vd., 2018) ve gıdaların içerdiği suyun önemli bir kısmının uzaklaştırılması esasına dayanmaktadır (Köse, 2018; Zhang vd., 2018). Findıkların kalite özelliklerini kaybetmeden muhafaza edilebilmesi için ise kurutma süreci sonrasında iç findık neminin \%6 değerinin altında olması tavsiye edilmektedir (Wang vd., 2018). Ayrica kurutma süresi meyve kalitesinin korunması bakımından hayati öneme sahiptir (Turan, 2019). Bu nedenle findığın toplandıktan sonra zuruflarının ayrılması ve kısa sürede kurutulması büyük önem arz etmektedir. Çünkü geç kurutulan findıklarda, küf gelişimi ve zararlılar tarafından hasar görme riski artmakta ve güneş ışı̆̆ının altında uzun süre kurtulan findıkların serbest yă̆ asitliğinin yükseldiği bilinmektedir (Fu vd., 2016; Qu vd., 2016; Turan, 2019). Ayrıca yüksek derecede doymamış yağ asitleri içeriğine sahip findıklar kurutma sirasında oksijen ve yüksek sicaklığa maruz kalmaları durumunda yağ oksidasyonuna karşı hassas duruma gelebilirler (Wang vd., 2018). $\mathrm{Bu}$ yüzden kurutma süreci yağ oksidasyonunu ve mikrobiyal aktivite gelişimini engellemek için çok dikkatli yürütülmelidir.

Türkiye'de geleneksel kurutma ortamlarından beton harmanın, çimen harmandan findık kurutma için daha uygun ortam olduğuna dair genel bir kanı mevcuttur. Ancak bu konuda günümüze kadar birkaç çalışma haricinde bilimsel araştırmalara dayalı detaylı veri bulunmamaktadır
(Turan, 2018a). Dahası, Türk findık çeşitlerinde suni ve geleneksel kurutma yöntemlerinin karşılaştırılması günümüze kadar kapsamlı bir şekilde maalesef yapılmamıştır (Turan ve İslam, 2016; Turan ve İslam, 2018; Turan, 2018b; Turan, 2019). Bu çalışma, geleneksel ve suni kurutma yöntemlerinin "Tombul" findık çeşidinin kimyasal özellikleri üzerinde muhafazası süresi boyunca meydana getirdiği değişiklikleri araştırarak oksidasyonunu en düşük düzeyde etkileyen kurutma metodunu belirlemek amaciyla yürütülmüştür.

\section{MATERYAL VE YÖNTEM}

\section{Materyal}

Çalışmada kullanılan "Tombul” findıklar Giresun İli Bulancak İlçesi Şemseddin Mahallesinde tek bir bahçeden alınmıştır (1 405 $55^{\prime} 31.90^{\prime \prime} \mathrm{N}$, $38^{\circ} 14^{\prime} 00.71^{\prime \prime}$ E, $\left.110 \mathrm{~m}\right)$. Örnek alınan bahçelerdeki dal sayısı $\sim 5-7 \mathrm{dal} /$ ocak, ocak arası mesafe $\sim 3 \mathrm{~m}$, dekara ocak sayıs $\sim 60$ bitki/da ve bahçe $\sim 30$ yaşındaki bitkilerden oluşmaktadır. Genellikle yılda iki defa dip sürgünü temizliği yapıldığ1 gözlenmiş, yaşlı dallar geleneksel yöntemlerle seyreltilmiş ancak bahçede gençleştirme tamamen yapılamamıştır. Gübreleme genelde Mart ayının ortasinda 1 $\mathrm{kg}$ /ocak olacak şekilde serpme uygulanmaktadır $(\mathrm{CAN}, \% 26 \mathrm{~N})$. Zararlilardan sadece findik kurduna (Curculio nucum L.) karșı genelde Mayıs ayının başında mücadele yapılmaktadır (\%50 methiocarp wp, $100 \mathrm{~g} / \mathrm{da}$ ). Ancak yoğun zarar1 olduğu gözlenen dalkıran zararlısı (Xyloborus dispar F.) ve külleme hastalığına [Phyllactinia guttata (Wallr.; Fr.) Lev] karş1 mücadele yapılmadığ1 gözlenmiştir. Y1llik ortalama verim ise $60-80$ $\mathrm{kg} / \mathrm{da}$ arasında değişkenlik göstermektedir.

\section{Yöntem}

\section{Kurutma yöntemleri}

Hasat işlemi 08-19 Ağustos 2014 tarihleri arasinda $\sim 25$ nem değerinde (Refsan RK 55, Kütahya, Turkey) yerden hasat şeklinde gerçekleştirilmiştir (Turan ve İslam, 2016). Hasat edilen findiklar çimen harmana serilmiş ve çotanaklı halde $\sim 3$ gün soldurulmuştur (Nem değeri \%16.51). Soldurulan findıklar (22 Ağustos 2014) daha sonra patoz yardımıyla (Dinçler Makine, FPHM 2500, Samsun, Turkey) 
çotanaklarından ayrllmış ve kurutma işlemi için üç gruba ayrılmıştır. . Grup I; çotanaklarından ayrılmış findıklar otu motorla biçilmiş (Oleo-Mac $440 \mathrm{~T}$, Italy) çimen harmana (ÇH; $4 \times 3 \mathrm{~m}$ boyut, $\sim 30 \mathrm{~kg}$ ) getirilmiş ve yere serilen branda üzerine (TS 4739, TS 1534-2; EN ISO 2286-2, Kale Tente, İstanbul, Turkey) $5 \mathrm{~cm}$ kalınlığında serilmiş ve güneş altında günde en az 3 defa (sabah, öğle ve akşam) karıştırılmıştır. Grup II; findıklar doğrudan beton harmana (BH; $5 \times 5$ m boyut, $\sim 30$ kg) serilmiş (TS EN 12390 Gümüşteş Çimento, Giresun, Türkiye) ve güneş altında iklime bağlı olarak günde en az 3 defa karıştırılmıştır. ÇH ve BH metotlarında örnekler ortam şartlarında kurutulmuştur (ortalama rüzgar hız1, ortam sıcaklı̆̆1 ve nemi ve güneşlenme süresi; $1.4 \mathrm{sa} / \mathrm{km}$, $25.6^{\circ} \mathrm{C}$ ve 5.24 sa, sirasiyla). ÇH ve $\mathrm{BH}$ metotlarında kurutma işlemi her gün saat 08:0020:00 arasında devam etmiş ve 20:00'dan sonra findıkların nem almaması için üzeri naylon örtü (Metroplast, İstanbul, Türkiye) ile örtülmüsstür (Yaygin uygulama). Grup III; findıklar kurutma makinesi (KM) içerisine elevatör yardımıyla yerleştirilmiş $(\sim 1000 \mathrm{~kg})$ ve kurutma işlemi $45^{\circ} \mathrm{C}$ 'de (yaygin kullanım) (FACMA ES 3000,
2013, İtalya; [Turan ve İslam, 2018]) gerçekleştirilmiştir ( $30 \mathrm{~kg}$ tesadüfen seçilmiş). Sicak hava ventilator $(1.5 \mathrm{~m} / \mathrm{s}$ hava hız1) yardımıyla kurutucuya iletilmiş ve kurutma süresince arşimet vidası sürekli karıştırma işlemine devam etmiştir. Kurutma süresince 3 sa sicak hava pompalanmış ve 1.5 sa durdurulmuştur. Bu $1.5 \mathrm{sa}$ süresince ve kurutma süresince saat 20:00-08:00 arası dahil arşimet vidası karıştırma işlemine devam etmiştir. Kurutma işlemi iç findık nem değeri \%6'nin altına düşene kadar devam ettirilmiştir (Turan ve İslam, 2016). Kurutma süreci beton ve çimen harmanda $80 \mathrm{sa}$, kurutma makinesinde ise 28 sa sürmüştür. Kuruma süresi ve nem değerleri ile ilgili detaylar Şekil 1'de gösterilmiştir. Kurutma işlemi 22-26 Ağustos 2014 tarihleri arasında Ordu ili, Altınordu ilçesi, Karapinar mahallesi $\left(40^{\circ} 58^{\prime \prime} 17.53 \mathrm{~K}, 37^{\circ} 56^{\prime \prime} 00.41\right.$ $\mathrm{D}$, rakım $43 \mathrm{~m}$ ), Organize Sanayi Bölgesinde (Ordu OSB, Gürsoy Tarımsal Ürünler Gıda Sanayi ve Ticaret A.Ş. Entegre Tesisi) yürütülmüştür (Turan, 2018a; Turan, 2019).

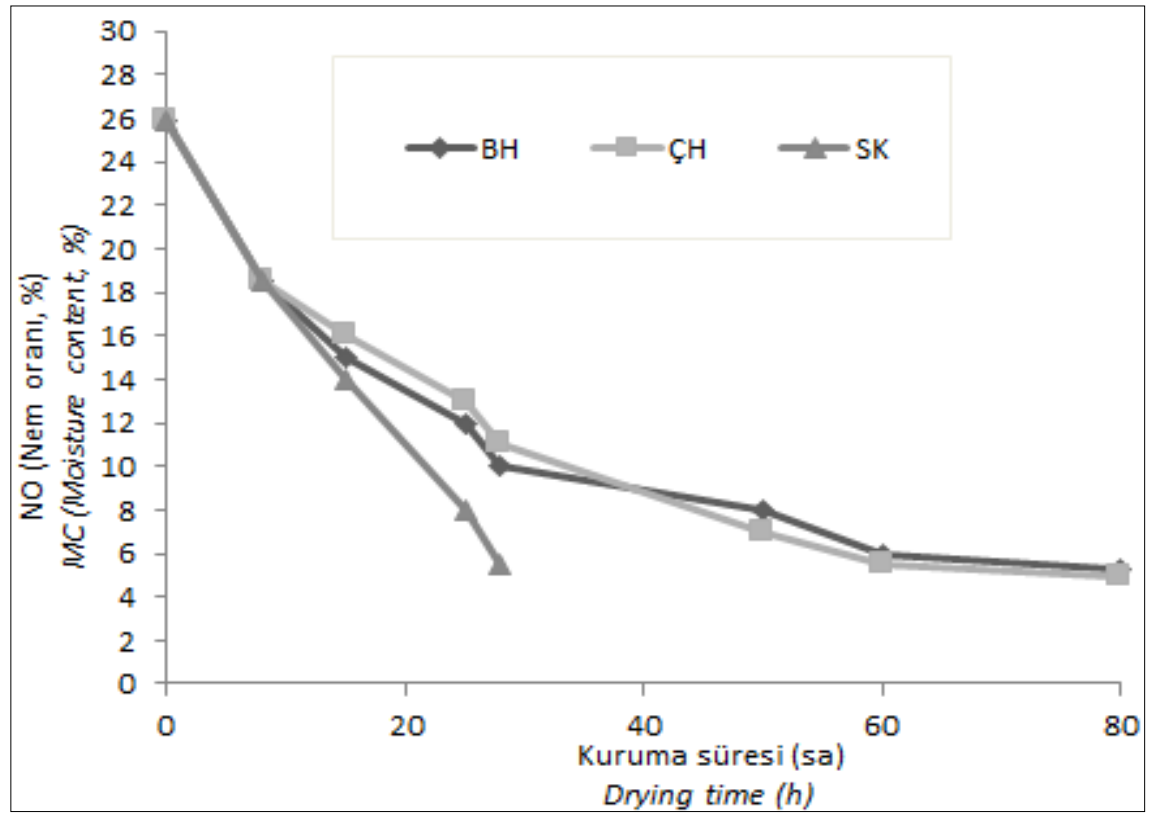

Şekil 1 Findığın suni ve güneşte kuruma süreleri ile kuruma eğrisi (Güneşte kurutma: $\mathrm{BH}$; Beton harman, ÇH; Çimen Harman ve SK; Suni kurutma)

Figure 1 Drying graph for in-shell hazelnut during conventional (sun-dried: BH; concrete ground and CH; grass ground) and artificial dried (SK). 


\section{Depolama şartlar1}

Kurutulmuş findıklar $10 \mathrm{~kg}$ jüt çuvallarda, palet üzerinde adi depo şartlarında $\left(20-25^{\circ} \mathrm{C}\right.$ ve $70 \%$ 90 nispi nem) 18 ay depolanmıştır.

\section{Yağ ekstraksiyonu}

Findık yağı Ceselsan soğuk pres yağ ekstraksiyon sistemi ile (AISI3004, Ceselsan, Giresun, Türkiye) elde edilmiştir (Basınç kuvveti: 10000 kgf, basınç: 34.7 MPa, sicaklık:- ${ }^{\circ} \mathrm{C} \sim+45{ }^{\circ} \mathrm{C}$ ve kapasite; 250 $\mathrm{g}$ iç findık; Turan, 2018a).

\section{Protein ve yağ oranı}

Protein oranı AOAC standart metoduna göre $(\mathrm{N} \times 6.25), 0.5 \mathrm{~g}$ örnek kullanılmış ve makro Kjehldahl metodu (metot 940.26) ile (Velp UDK 149, Europe), yağ oranı ise AOAC metoduna göre (AOAC, 2000), $5 \mathrm{~g}$ örneğin soxelet cihazında $\left(110^{\circ} \mathrm{C}\right.$ sicaklik) petrol eteri ektraksiyonu (metot 960.39) ile elde edilmiştir (Velp Ser 148, Milano, Italy).

\section{Nem oran1 ve su aktivitesi}

Nem oranı, Türk Standartları Enstitüsü (EN ISO 65-2000)-TS 3075/T1 iç findık standardına göre yapılmıştır (Kösal, 2018; Turan, 2019). Kıyılmış findiklar (Fakir Motto $800 \mathrm{w}$, Germany) $105^{\circ} \mathrm{C}$ sicaklıkta sabit bir ağırlığa (Refsan RK 55, Kütahya, Turkey) ulaşıncaya kadar bekletilmiştir. Su aktivitesi ise $\left(a_{w}\right)$ Novasina $a_{w}$ Sprint TH 500 (Switzerland) cihazı kullanılarak yapılmıştır (WAA, 2004).

\section{Aflatoksin miktarının belirlenmesi}

Total aflatoksin (AF) ve aflatoksin B1 (AFB1) HPLC cihaz1 (Shimadzu, c2101390892100, RF:10AXL, Japan) kullanılarak elde edilmiştir. $125 \pm 0.1 \mathrm{~g}$ örnek $0.01 \mathrm{~g}$ hassasiyette terazide tartılmış, $4 \mathrm{~g} \mathrm{NaCl}, 150 \mathrm{ml} \mathrm{CH} 3 \mathrm{OH}+25 \mathrm{ml} \mathrm{saf} \mathrm{su}$ ile $3 \mathrm{dk}$ karıştırılmış ve katlı filtre kağıdından süzülmüştür. Süzülen örnekten $10 \mathrm{ml}$ alınmış ve $10 \mathrm{ml}$ saf su ile karıştırılmış, toplam $20 \mathrm{ml}$ karışımdan $10 \mathrm{ml}$ immunoafinity kolondan (1-2

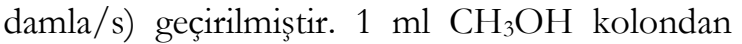
geçirilerek aflatoksin elüe edilmiş (1 damla/s), 1 ml HPLC grade saf su kolondan geçirilmiş (2 damla/s) ve $5 \mathrm{ml}$ hacimli anber cam kapta toplanmıştır (toplam hacim $2 \mathrm{ml}$ ). $50 \mu \mathrm{l}$ 'si HPLC cihazına enjekte edilmiş ve toplam aflatoksin ve aflatoksin B1; m (ng/g) $=50 \mathrm{~g} / 250 \mathrm{mLX} 5 \mathrm{~mL} / 2$ $\mathrm{mL}$ formülü ile hesaplanmıştır (Turan ve İslam, 2018).

\section{Yağ asitleri kompozisyonu}

Yağ asitleri kompozisyonu gaz kromotografisi ile (Shimadzu GC-2010, Tokyo, Japan), yağ asidi metil esterlerinin elde edilmesinde ise Ficarra et al. (2010)'a küçük modifikasyon yapılarak Turan (2018a) ve Turan (2019)' a göre yapılmıştır.

\section{Oksidasyon parametreleri}

Serbest yağ asitliği (metot Cd 3d-63) AOCS Standard Method (AOCS, 2004)'a, peroksit değeri (metot Cd 8-53) AOCS (AOCS, 2004) (Metrohm, Dosimat 799, Switzerland), ransimat değeri, rancimat 743 device (Metrohm, Switzerland; Velasco vd. 2004)'e göre yapılmıştır. İyot değeri (ID) ise yă̆ asitleri yüzdesi (Hashempour vd., 2010; Belviso vd., 2017; Turan, 2018a; Turan, 2019) ile hesaplanmıştır (1).

$\mathrm{ID}=(\mathrm{C} 16: 1 \times 1.901)+(\mathrm{C} 18: 1 \times 0.899)+$

$(\mathrm{C} 18: 2 \times 1.814)+(\mathrm{C} 18: 3 \times 2.737)$

\section{Istatistiksel analizler}

Deneme tesadüf blokları deneme desenine göre üç tekerrürlü olarak yürütülmüştür. Tanımlayıc1 istatistikler SPSS v. 22.0'e göre (Armok, New York: IBM Corp.), istatistiki testler ise SASJAMP v. 10.0 (SAS Institute Inc., Cary, North Carolina) kullanılarak yapılmıştır.

\section{BULGULAR VE TARTIŞMA \\ Protein orant}

Protein oranı (PO) üzerine kurutma yöntemleri ve muhafaza süresinin etkisi ile ilgili veriler Çizelge 1'de verilmiştir. Kurutma yöntemlerinin protein oranına etkisi önemli bulunmuş $(P<0.05$; Çizelge 1), ve bu değer \% 4.15 (SK, 12. ay) ve \%16.71 (SK, 18. ay) aralığında değişmiştir. Çalışmamız, Delgado vd. (2017) tarafindan kestanelerde (7.00$8.52 \mathrm{~g} / 100 \mathrm{~g}$ kuru madde) tespit edilen sonuçlarla benzerlik göstermiş, ancak Turan ve İslam (2016) ve Kermani vd. (2017) tarafindan elde edilen sonuçlarla farklılık göstermiştir. Protein oranı üzerine muhafaza süresinin etkisi ise istatistiksel olarak önemli bulunmuş $(P<0.001)$, muhafaza süresince $\mathrm{PO}$ değeri dalgalanma göstermekle 
birlikte depolama sonundaki değerler başlangiç değerlerinden daha yüksek olmuştur (\%15.6116.71). PO değerinde yaşanan bu tür dalgalanmalar nem değerindeki değişmelerden kaynaklanmış olabilir, çünkü genel olarak muhafaza süresinin $\mathrm{PO}$ değerini etkilemediği belirtilmektedir (Telgado vd., 2017). Ayrica, Turan ve İslam (2016) ve Koç Güler vd. (2017) çalışmalarında, PO değerinin muhafaza süresince dalgalanmakla birlikte muhafaza süresince azaldığını bildirmişlerdir.

Çizelge 1 Kurutma yöntemlerinin 18 ay depolama süresince findığın protein, yăg, nem oranı ve su aktivitesi değeri üzerine etkileri

Table 1 Effect of drying methods on protein, lipid and, moisture content and water activity of hazelnut during 18 months of storage periods

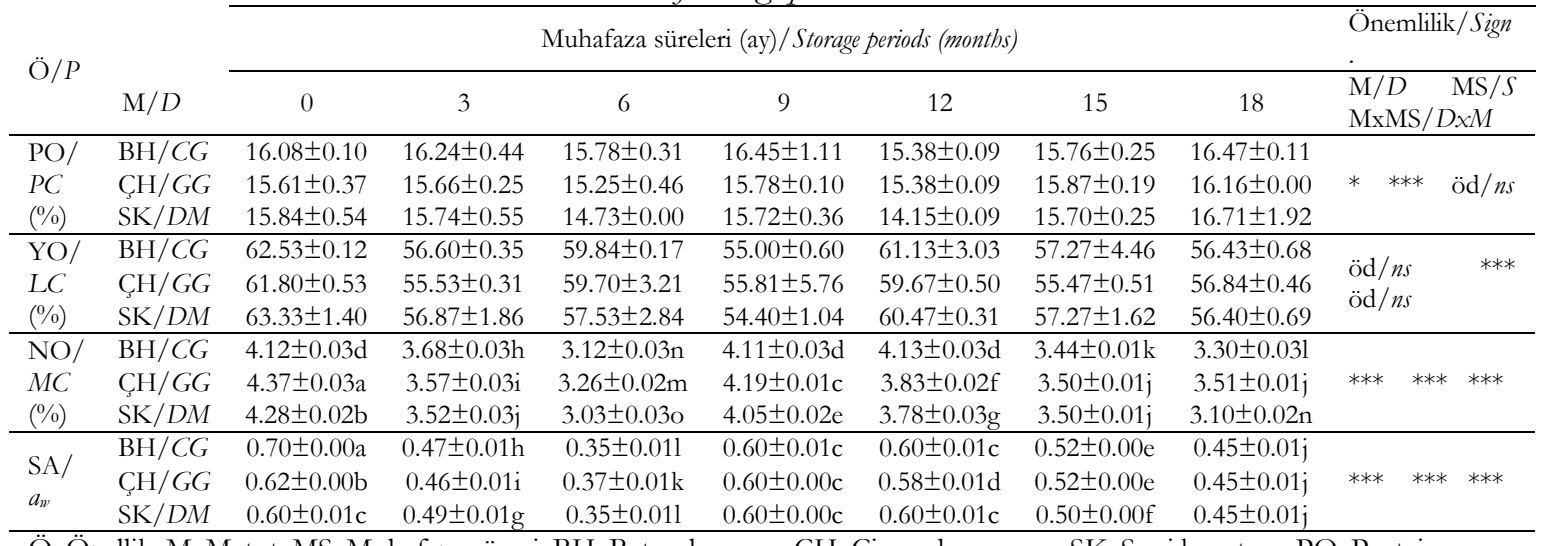

Ö: Özellik, M: Metot, MS: Muhafaza süresi, BH: Beton harman, ÇH: Çimen harman ve SK: Suni kurutma. PO: Protein oranı, YO: Yağ oranı, NO: Nem oranı ve SA: Su aktivitesi. Ortalama \pm SD şeklinde ifade edilmiştir. Kurutma yöntemleri ve depolama süreleri arasındaki farklılıklar farklı harflerle gösterilmiştir. Önem seviyeleri; *, **, *** ve "öd” $P<0.05,0.01,0.001$ ve "önemli değil"

P: Parameter, D: Drying, S: Storage periods, CG: Concrete ground, GG: Grass ground and DM: Drying machine. PC: Protein content, LC: Lipid content, MC: Moisture content and $a_{w}$ : Water activity. Values are expressed as mean \pm standard deviation. Different letters in columns for each different drying, mean significantly different values among storage time. Significant level; *, **, *** and "ns" mean significance at $P$ $<0.05,0.01,0.001$ and "not significant", respectively, between drying and storage time.

\section{Yă̆ oran1}

Çalışmamızda kurutma yöntemlerinin yağ oranı (YO) üzerine etkisi istatistiksel olarak önemsiz bulunmuş $(P>0.05)$ ve depolama süresince $\mathrm{YO}$ değeri \%54.40 (SK, 9. ay) 63.33 (SK, başlangiç) aralığında değişmiştir. Kurutma yöntemlerinin YO değerini etkilemediğini bildiren benzer çalışmaların yanı sıra (Turan ve İslam, 2016; Kermani vd., 2017), etkilediğini bildiren (2.22$3.13 \mathrm{~g} / 100 \mathrm{~g}$ kuru madde) başka çalışmalarda bulunmaktadır (Delgado vd., 2017). Tespit edilen bu farkl1lıklar tür, çeşit ya da kurutma yöntemleri ve depolama koşulları gibi bazı etmenlerden kaynaklanmış olabilir. Muhafaza süresince ise beklendiği gibi YO değeri biraz dalgalanma göstermekle birlikte genel olarak azalma eğilimi göstermiştir ( $P$ <0.001; Çizelge 1). Ortam şartlarında muhafaza edilen findıklarda genel olarak bu yönde bir eğilim gösterdiği bilinmektedir (Turan ve İslam, 2016). Ancak Ghirardello vd. (2013) ortam şartlarında muhafaza edilen findıklarda YO değerinin arttı̆̆ını, Koç Güler vd. (2017) ise etkilemediğini bildirmiştir. Tespit edilen bu farkllliklar muhtemelen ortam nemi, kabuk ya da iç findık özellikleri farklılığından kaynaklanmış olabilir.

\section{Nem oran1}

Findıkların kalite özellikleri bozulmadan muhafaza edilmesi için nem değerinin (NO) \%5 eşik değerini aşmaması önerilmektedir (Özdemir vd., 1998). Türkiye'de findık alım esaslarına göre ise nem oranının $\leq \% 6$ altında olması gerektiği, aksi halde findıkların satın alınmadığ bilinmektedir. Kurutma yöntemlerinin nem oranı üzerine etkisi istatistikî olarak önemli görülmüşs $(P$ 
$<0.001$ ), ve en düşük değer \%3.03 ile SK yönteminde 6 . ayda, en yüksek değer ise $\% 4.37$ ile ÇH yönteminde başlangıçta belirlenmiştir. Muhafaza süresinin nem oranı üzerine etkisi ise istatistikî olarak önemli bulunmuş $(P<0.001$; Çizelge 1) ve bu değer dalgalanma göstermekle birlikte genelde azalmıştır. Çalışmamızda olduğu gibi findıkta nem değerinin muhafaza süresince genellikle azalmakla birlikte dalgalanma gösterdiğini bildiren çalışmalar bulunmaktadır (Turan ve İslam, 2016; Koç Güler vd., 2017; Turan, 2019).

\section{Su aktivitesi}

Su aktivitesi $\left(a_{w}\right)$ gidalarda yağ oksidasyonunu etkileyen en önemli parametrelerden birisi olarak görülmektedir (Turan, 2018a). Ayrıca $a_{w}$ değeri 0.3-0.5 aralı̆̆ında yağ oksidasyonunun oldukça düşük olduğu ve bu yüzden iç findık neminin $<\% 5$ değerinin altında olması gerektiği bilinmektedir. Kurutma yöntemleri arasında Turan ve İslam (2016)' 'n çalışmalarında olduğu gibi en yüksek değer $\mathrm{BH}$ ve ÇH (sirasiyla $0.70, \quad 0.62$ ) metotlarında, en düşük değer ise SK (0.60) metodunda belirlenmiş ve aradaki farklılık önemli görülmüştür $(P<0.001$; Çizelge 1$)$. Çalışmamızda $a_{w}$ değeri NO değerinin değişimine benzer eğilim göstermiş ve muhafaza süresince 0.35 (BH ve $\mathrm{SK}$, 6. ay) $-0.70(\mathrm{BH}$, başlangıç) aralığında seyretmiştir. $a_{w}$ değerinin muhafaza süresince dalgalı eğilimi bazı dönemlerde Turan ve İslam (2016) ve Koç Güler vd. (2017) çalışmaları ile benzerlik gösterse de, muhafaza süresince azalma eğiliminde olduğu görülmüştür. Ayrıca $a_{w}$ değerinin iki gün süreyle 0.83 'ü aşması durumunda aflatoksinin oluşabileceği, bu nedenle eşik değerini asla aşmaması gerektiği bildirilmiştir (Özay vd., 2008). Çalışmamızda ise elde edilen $a_{w}$ değerlerinin tamamı 0.72'nin altında olması sebebiyle böyle bir risk oluşmamışır.

\section{Aflatoksin}

Türkiye'de findiklar genellikle beton ya da çimen harmanda güneş altında kurutulmaktadır. Güneşte kurutma süresince ürünün iklime bağl1 yeniden nem alma ihtimali yüzünden küf gelişimi ve mikotoksin riski yüksektir (Özay vd. 2008; Başaran, 2010; Turan ve İslam, 2018). Bu nedenle findığın hızlı kurutulması ve nem değerinin $\% 5$ 'in altına düşürülmesi büyük önem arz etmektedir. Aksi halde aflatoksin oluşum ve gelişimi sonucunda ürünün zarar görmesi muhtemeldir. Ancak çalışmamızda, beklenenin aksi yönde gelişme olmuş ve özellikle $\mathrm{BH}$ ve ÇH metotları ile muhafaza ortamı aflatoksin gelişimi için uygun koşulları sağlamasina rağmen söz konusu etmen tespit edilmemiştir $(<0.1 \mathrm{ng} / \mathrm{g})$. Elde edilen bu verilerden, Turan ve İslam (2016) ve Turan ve İslam (2018)'de belirtildiği gibi aflatoksinin meyvenin gelişimi aşamasında oluşmamısssa sonradan şartların uygun olması halinde bile gelişmediği görülmüştür.

\section{Yağ asitleri kompozisyonu}

Çizelge 2'de görüldüğü gibi Tombul çeşidi toplam 13 yağ asidi içermekte olup, bunlar arasında en yüksek oranda oleik asit (C18:1), bunu linoleik (C18:2), palmitik (C16:0), ve stearik (C18:0) yă̆ asitleri takip etmiş ve kurutma metotları ile depolamanın etkisi istatistiksel olarak önemli görülmüsstür $(P<0.001)$. Ayrıca çalışmada kaproik asit (C6:0), kaprilik (C8: 0), kaprik (C10:0), laurik (C12:0), eikosadienoik (C20:2), erusik (C22:1), dokosadienoik (C22:2) ve lignoserik (C24:0) yağ asitleri tespit edilecek düzeyde bulunamamışır (<\%0.001). Çalışmamızda majör grup, toplam yă̆ asitlerinin $\sim \% 99.00$ 'sini oluştururken minör grup ise toplam yağ asitlerinin $\sim \% 0.5$ ' lik kısmını oluşturmuştur (Çizelge 2). Yağ asitleri kompozisyonu üzerine çeşit, orijin, yetişme koşulları, olgunluk, gübreleme, hasat zaman1, sezon, toprak tipi, iklim, rakım ve depolama koşulları gibi pek çok faktör etki etmektedir (Amaral vd., 2006; Alaşalvar vd., 2010; Hashempour vd., 2010; Jawnowciz ve Lenart, 2018). Örneğin, Tüfekçi ve Karataş (2018) Orta Karadeniz Bölgesi findıklarının yüksek miktarda doymuş (\%8.45) ve tekli doymamış yağ asidi (\%83.45), fakat düşük miktarda çoklu doymamış yă̆ asidi (\%7.8) içerdiğini, Doğu Karadeniz Bölgesi findıklarının ise yüksek miktarda linoleik $(\% 9.10)$ ve linolenik $(\% 0.09)$ asit içerdiğini bildirmiştir. Ayrıca Alaşalvar vd. (2010) "Tombul" çeşidinin \%5.61 palmitik (C16:0), \%82.16 oleik (C18:1) ve \% 8.26 linoleik (C18:2) asit içerdiğini, "Palaz" çeşidinin ise \%6.64 palmitik (C16:0), \%81.97 oleik (C18:1) ve \%8.32 linoleik (C18:2) asit içerdiğini, Çakıldak çeşidinin 
ise $\% 5.02$ palmitik (C16:0), \%80.99 oleik (C18:1) ve $\% 10.63$ linoleik (C18:2) asit içerdiğini bildirmiştir. Turan (2018a) ise Ordu Levant findıklarının \%3.84 palmitik (C16:0), \%84.51 oleik (C18:1) ve \%10.04 linoleik (C18:2) asit içerdiğini bildirmiştir.

Çizelge 2 Kurutma yöntemlerinin findığın 18 ay depolama süresince yağ asitleri kompozisyonu üzerine etkileri

Table 2 Effect of drying methods on fatty acids composition of hazelnut during 18 months of storage periods.

\begin{tabular}{|c|c|c|c|c|c|c|c|c|c|}
\hline \multirow{2}{*}{$\ddot{O} / P$} & & \multicolumn{7}{|c|}{ Muhafaza süreleri (ay)/Storage periods (months) } & \multirow{2}{*}{$\begin{array}{c}\text { Önemlili } \\
\text { k/Sign. } \\
\mathrm{M} / D \\
\mathrm{MS} / \mathrm{S} \\
\mathrm{MxMS} / \\
D x M \\
\end{array}$} \\
\hline & $\mathrm{M} / \mathrm{D}$ & 0 & 3 & 6 & 9 & 12 & 15 & 18 & \\
\hline \multirow{3}{*}{$\begin{array}{c}\text { C14:O } \\
(\%)\end{array}$} & $\mathrm{BH} / \mathrm{CG}$ & $0.02 \pm 0.01 \mathrm{de}$ & $0.02 \pm 0.01 \mathrm{de}$ & $0.02 \pm 0.00 \mathrm{e}$ & $0.03 \pm 0.01 \mathrm{de}$ & $0.04 \pm 0.00 \mathrm{c}$ & $0.05 \pm 0.01 \mathrm{abc}$ & $0.05 \pm 0.00 \mathrm{ab}$ & \multirow{3}{*}{ 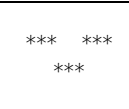 } \\
\hline & $\mathrm{C} \mathrm{H} / G G$ & $0.02 \pm 0.01 \mathrm{de}$ & $0.02 \pm 0.01 \mathrm{de}$ & $0.04 \pm 0.00 \mathrm{c}$ & $0.05 \pm 0.01 \mathrm{abc}$ & $0.04 \pm 0.01 \mathrm{bc}$ & $0.05 \pm 0.01 \mathrm{a}$ & $0.05 \pm 0.00 \mathrm{ab}$ & \\
\hline & $\mathrm{SK} / D M$ & $0.03 \pm 0.01 \mathrm{~d}$ & $0.03 \pm 0.01 \mathrm{~d}$ & $0.04 \pm 0.01 \mathrm{bc}$ & $0.05 \pm 0.00 \mathrm{ab}$ & $0.05 \pm 0.01 \mathrm{abc}$ & $0.05 \pm 0.00 \mathrm{ab}$ & $0.04 \pm 0.01 \mathrm{bc}$ & \\
\hline \multirow{3}{*}{$\begin{array}{r}\mathrm{C} 1: \mathrm{O} \\
(\%)\end{array}$} & $\mathrm{BH} / \mathrm{CG}$ & $4.19 \pm 0.11 \mathrm{de}$ & $4.19 \pm 0.11 \mathrm{de}$ & $4.29 \pm 0.03 \mathrm{cde}$ & $4.31 \pm 0.02 \mathrm{~cd}$ & $4.29 \pm 0.02 \mathrm{cde}$ & $4.53 \pm 0.02 \mathrm{~b}$ & $4.53 \pm 0.01 \mathrm{~b}$ & \multirow{3}{*}{$\begin{array}{c}* * * \quad * * * \\
* * *\end{array}$} \\
\hline & $\mathrm{C} \mathrm{H} / G G$ & $3.80 \pm 0.16 \mathrm{gh}$ & $3.71 \pm 0.10 \mathrm{~h}$ & $3.78 \pm 0.01 \mathrm{gh}$ & $3.79 \pm 0.01 \mathrm{gh}$ & $3.78 \pm 0.01 \mathrm{gh}$ & $4.39 \pm 0.01 \mathrm{bc}$ & $4.40 \pm 0.01 \mathrm{bc}$ & \\
\hline & $\mathrm{SK} / D M$ & $3.94 \pm 0.07 \mathrm{fg}$ & $3.94 \pm 0.05 \mathrm{fg}$ & $4.75 \pm 0.44 \mathrm{a}$ & $4.40 \pm 0.01 \mathrm{bc}$ & $4.39 \pm 0.03 \mathrm{bc}$ & $4.13 \pm 0.02 \mathrm{de}$ & $4.12 \pm 0.01 \mathrm{ef}$ & \\
\hline \multirow{3}{*}{$\begin{array}{l}\text { C16:1 } \\
(\%)\end{array}$} & $\mathrm{BH} / C G$ & $0.08 \pm 0.01 \mathrm{bc}$ & $0.09 \pm 0.01 \mathrm{bc}$ & $0.08 \pm 0.01 \mathrm{cde}$ & $0.07 \pm 0.01 \mathrm{def}$ & $0.08 \pm 0.01 \mathrm{cde}$ & $0.10 \pm 0.01 \mathrm{ab}$ & $0.10 \pm 0.00 \mathrm{a}$ & \multirow{3}{*}{$\begin{array}{c}* * * \quad * * \\
* * *\end{array}$} \\
\hline & $\mathrm{C} \mathrm{H} / G G$ & $0.07 \pm 0.01$ cde & $0.09 \pm 0.01 \mathrm{bc}$ & $0.08 \pm 0.01 \mathrm{~cd}$ & $0.09 \pm 0.01 b c$ & $0.10 \pm 0.01 \mathrm{ab}$ & $0.07 \pm 0.01 \mathrm{def}$ & $0.08 \pm 0.01 \mathrm{cde}$ & \\
\hline & $\mathrm{SK} / D M$ & $0.07 \pm 0.01 \mathrm{efg}$ & $0.07 \pm 0.01 \mathrm{efg}$ & $0.05 \pm 0.01 \mathrm{~h}$ & $0.06 \pm 0.01 \mathrm{fgh}$ & $0.06 \pm 0.00 \mathrm{gh}$ & $0.08 \pm 0.01 \mathrm{cde}$ & $0.07 \pm 0.01 \mathrm{def}$ & \\
\hline \multirow{3}{*}{$\begin{array}{c}\mathrm{C} 17: \mathrm{O} \\
(\%)\end{array}$} & $\mathrm{BH} / \mathrm{CG}$ & $0.02 \pm 0.01$ & $0.02 \pm 0.01$ & $0.03 \pm 0.01$ & $0.02 \pm 0.01$ & $0.03 \pm 0.00$ & $0.05 \pm 0.01$ & $0.05 \pm 0.00$ & \multirow{3}{*}{$\begin{array}{c}\text { *** }{ }^{* * *} \\
\mathrm{od} / n s\end{array}$} \\
\hline & $\mathrm{C} \mathrm{H} / G G$ & $0.03 \pm 0.00$ & $0.03 \pm 0.01$ & $0.02 \pm 0.01$ & $0.03 \pm 0.01$ & $0.04 \pm 0.01$ & $0.06 \pm 0.00$ & $0.05 \pm 0.01$ & \\
\hline & $\mathrm{SK} / D M$ & $0.03 \pm 0.01$ & $0.04 \pm 0.01$ & $0.03 \pm 0.02$ & $0.05 \pm 0.01$ & $0.05 \pm 0.00$ & $0.06 \pm 0.01$ & $0.06 \pm 0.00$ & \\
\hline \multirow{3}{*}{$\begin{array}{c}\text { C17:1 } \\
(\%)\end{array}$} & $\mathrm{BH} / C \mathrm{CG}$ & $0.05 \pm 0.01$ & $0.05 \pm 0.01$ & $0.06 \pm 0.00$ & $0.06 \pm 0.01$ & $0.06 \pm 0.00$ & $0.06 \pm 0.01$ & $0.05 \pm 0.01$ & \multirow{3}{*}{$\begin{array}{l}\mathrm{od} / n s \\
\mathrm{od} / n s \\
\mathrm{od} / n s\end{array}$} \\
\hline & $\mathrm{C} \mathrm{H} / G G$ & $0.05 \pm 0.01$ & $0.06 \pm 0.01$ & $0.05 \pm 0.00$ & $0.04 \pm 0.01$ & $0.04 \pm 0.00$ & $0.06 \pm 0.01$ & $0.05 \pm 0.01$ & \\
\hline & $\mathrm{SK} / D M$ & $0.05 \pm 0.01$ & $0.05 \pm 0.01$ & $0.05 \pm 0.03$ & $0.05 \pm 0.01$ & $0.05 \pm 0.01$ & $0.06 \pm 0.00$ & $0.05 \pm 0.01$ & \\
\hline \multirow{3}{*}{$\begin{array}{c}\text { C18:0 } \\
(\%)\end{array}$} & $\mathrm{BH} / \mathrm{CG}$ & $1.93 \pm 0.04 \mathrm{~cd}$ & $1.93 \pm 0.04 \mathrm{~cd}$ & $1.90 \pm 0.03 \mathrm{cde}$ & $1.87 \pm 0.01 \mathrm{def}$ & $1.86 \pm 0.01 \mathrm{efg}$ & $2.56 \pm 0.01 \mathrm{a}$ & $2.54 \pm 0.01 \mathrm{a}$ & \multirow{3}{*}{$\begin{array}{c}\text { *** }{ }^{* * *} \\
* * *\end{array}$} \\
\hline & $\mathrm{C} \mathrm{H} / G G$ & $1.85 \pm 0.05 \mathrm{efg}$ & $1.86 \pm 0.05 \mathrm{efg}$ & $1.79 \pm 0.06 \mathrm{gh}$ & $1.80 \pm 0.02 \mathrm{fgh}$ & $1.80 \pm 0.01 \mathrm{fgh}$ & $1.60 \pm 0.01 \mathrm{i}$ & $1.55 \pm 0.01 \mathrm{i}$ & \\
\hline & $\mathrm{SK} / D M$ & $2.09 \pm 0.16 \mathrm{~b}$ & $1.95 \pm 0.01 \mathrm{c}$ & $1.87 \pm 0.03 \mathrm{de}$ & $1.80 \pm 0.02 \mathrm{fgh}$ & $1.78 \pm 0.01 \mathrm{~h}$ & $2.11 \pm 0.02 \mathrm{~b}$ & $2.09 \pm 0.02 \mathrm{~b}$ & \\
\hline \multirow{3}{*}{$\begin{array}{c}\text { C18:1 } \\
(\%)\end{array}$} & $\mathrm{BH} / \mathrm{CG}$ & $84.17 \pm 0.03 a$ & $84.14 \pm 0.05 \mathrm{ab}$ & $84.02 \pm 0.02 \mathrm{ac}$ & $84.02 \pm 0.01 \mathrm{abc}$ & $84.00 \pm 0.02 \mathrm{a}-\mathrm{d}$ & $81.90 \pm 0.02 \mathrm{~g}$ & $81.91 \pm 0.02 \mathrm{~g}$ & \\
\hline & $\mathrm{C} \mathrm{H} / G G$ & $83.92 \pm 0.06 \mathrm{bd}$ & $83.90 \pm 0.02 \mathrm{bd}$ & $83.91 \pm 0.04 \mathrm{bd}$ & $83.79 \pm 0.01 \mathrm{~cd}$ & $83.77 \pm 0.03 \mathrm{~d}$ & $82.10 \pm 0.02 \mathrm{~g}$ & $82.10 \pm 0.01 \mathrm{~g}$ & \\
\hline & $\mathrm{SK} / D M$ & $84.22 \pm 0.19 \mathrm{a}$ & $84.03 \pm 0.06 \mathrm{ab}$ & $82.75 \pm 0.62 \mathrm{e}$ & $82.50 \pm 0.05 f$ & $82.50 \pm 0.01 \mathrm{f}$ & $81.11 \pm 0.05 \mathrm{~h}$ & $81.11 \pm 0.02 \mathrm{~h}$ & \\
\hline & $\mathrm{BH} / \mathrm{CG}$ & $9.31 \pm 0.17 f$ & $9.32 \pm 0.17 \mathrm{f}$ & $9.35 \pm 0.01 \mathrm{f}$ & $9.37 \pm 0.02 \mathrm{f}$ & $9.37 \pm 0.03 \mathrm{f}$ & $10.35 \pm 0.00 \mathrm{~d}$ & $10.34 \pm 0.02 \mathrm{~d}$ & \\
\hline & $\mathrm{C} H / \mathrm{GG}$ & $9.91 \pm 0.07 \mathrm{e}$ & $10.00 \pm 0.03 \mathrm{e}$ & $9.99 \pm 0.02 \mathrm{e}$ & $10.12 \pm 0.02 \mathrm{de}$ & $10.11 \pm 0.03 \mathrm{de}$ & $11.35 \pm 0.03 b$ & $11.40 \pm 0.02 \mathrm{~b}$ & **** \\
\hline & SK/DM & $9.19 \pm 0.05 \mathrm{f}$ & $9.51 \pm 0.09 \mathrm{f}$ & $10.12 \pm 0.87 \mathrm{de}$ & $10.73 \pm 0.03 c$ & $10.78 \pm 0.03 c$ & $12.05 \pm 0.05 a$ & $12.10 \pm 0.01 \mathrm{a}$ & \\
\hline & $\mathrm{BH} / \mathrm{CG}$ & $0.09 \pm 0.01 \mathrm{def}$ & $0.09 \pm 0.01 \mathrm{def}$ & $0.10 \pm 0.01 \mathrm{cde}$ & $0.09 \pm 0.01 \mathrm{def}$ & $0.10 \pm 0.01$ cde & $0.10 \pm 0.01$ cde & $0.09 \pm 0.01 \mathrm{def}$ & \\
\hline & $\mathrm{C} \mathrm{H} / \mathrm{GG}$ & $0.11 \pm 0.02 \mathrm{ab}$ & $0.12 \pm 0.01 \mathrm{a}$ & $0.10 \pm 0.00 \mathrm{~cd}$ & $0.09 \pm 0.01 \mathrm{efg}$ & $0.10 \pm 0.01 \mathrm{cde}$ & $0.10 \pm 0.00 \mathrm{~cd}$ & $0.10 \pm 0.01 \mathrm{cde}$ & $\begin{array}{c}* * * * * * \\
* * *\end{array}$ \\
\hline & SK/DM & $0.12 \pm 0.01 \mathrm{a}$ & $0.12 \pm 0.01 \mathrm{a}$ & $0.12 \pm 0.01 \mathrm{ab}$ & $0.11 \pm 0.01 b c$ & $0.10 \pm 0.01 \mathrm{cde}$ & $0.08 \pm 0.01 \mathrm{fg}$ & $0.08 \pm 0.00 \mathrm{~g}$ & \\
\hline & $\mathrm{BH} / \mathrm{CG}$ & $0.07 \pm 0.01 \mathrm{f}$ & $0.06 \pm 0.01 \mathrm{f}$ & $0.07 \pm 0.01 \mathrm{ef}$ & $0.06 \pm 0.01 \mathrm{f}$ & $0.07 \pm 0.01 \mathrm{ef}$ & $0.08 \pm 0.01 b c$ & $0.09 \pm 0.01 \mathrm{ab}$ & \\
\hline & $\mathrm{ÇH} / \mathrm{GG}$ & $0.08 \pm 0.00 \mathrm{bcd}$ & $0.08 \pm 0.01 \mathrm{~cd}$ & $0.08 \pm 0.00 \mathrm{bcd}$ & $0.09 \pm 0.01 \mathrm{ab}$ & $0.08 \pm 0.01 b c$ & $0.08 \pm 0.01 b c$ & $0.09 \pm 0.01 \mathrm{ab}$ & \\
\hline & SK/DM & $0.07 \pm 0.01 \mathrm{de}$ & $0.08 \pm 0.01 \mathrm{~cd}$ & $0.08 \pm 0.01 \mathrm{~cd}$ & $0.08 \pm 0.00 \mathrm{bcd}$ & $0.08 \pm 0.01 b c$ & $0.09 \pm 0.01 \mathrm{a}$ & $0.09 \pm 0.01 \mathrm{ab}$ & \\
\hline & $\mathrm{BH} / \mathrm{CG}$ & $0.03 \pm 0.01 \mathrm{hi}$ & $0.03 \pm 0.01 \mathrm{hi}$ & $0.03 \pm 0.00 \mathrm{i}$ & $0.03 \pm 0.01 \mathrm{i}$ & $0.04 \pm 0.00 \mathrm{~h}$ & $0.10 \pm 0.00 \mathrm{a}$ & $0.10 \pm 0.00 \mathrm{a}$ & \\
\hline $\begin{array}{ll}C 20: 1 \\
0 / 0\end{array}$ & $\mathrm{C} \mathrm{H} / \mathrm{GG}$ & $0.06 \pm 0.01 \mathrm{cde}$ & $0.07 \pm 0.01 \mathrm{bcd}$ & $0.07 \pm 0.01 \mathrm{bcd}$ & $0.06 \pm 0.01 \mathrm{def}$ & $0.06 \pm 0.01 \mathrm{efg}$ & $0.05 \pm 0.01 \mathrm{fg}$ & $0.05 \pm 0.00 \mathrm{~g}$ & $* * * \quad * * * * * *$ \\
\hline & SK/DM & $0.07 \pm 0.02 \mathrm{~b}$ & $0.07 \pm 0.00 \mathrm{bc}$ & $0.06 \pm 0.01 \mathrm{efg}$ & $0.06 \pm 0.00 \mathrm{def}$ & $0.06 \pm 0.01 \mathrm{efg}$ & $0.06 \pm 0.01 \mathrm{efg}$ & $0.05 \pm 0.00 \mathrm{~g}$ & \\
\hline & $\mathrm{BH} / \mathrm{CG}$ & $0.04 \pm 0.01 \mathrm{efg}$ & $0.03 \pm 0.01 \mathrm{fg}$ & $0.03 \pm 0.01 \mathrm{~g}$ & $0.03 \pm 0.01 \mathrm{fg}$ & $0.04 \pm 0.01 \mathrm{efg}$ & $0.05 \pm 0.00 \mathrm{abc}$ & $0.05 \pm 0.01 \mathrm{bcd}$ & \\
\hline & $\mathrm{C} H / \mathrm{GG}$ & $0.04 \pm 0.01 \mathrm{def}$ & $0.04 \pm 0.01 \mathrm{cde}$ & $0.05 \pm 0.01 \mathrm{bcd}$ & $0.04 \pm 0.01 \mathrm{cde}$ & $0.05 \pm 0.01 \mathrm{bcd}$ & $0.04 \pm 0.00 \mathrm{def}$ & $0.05 \pm 0.01 \mathrm{bcd}$ & $* * * \quad * * * * *$ \\
\hline & SK/DM & $0.05 \pm 0.01 \mathrm{ab}$ & $0.05 \pm 0.01 \mathrm{ab}$ & $0.03 \pm 0.01 \mathrm{fg}$ & $0.05 \pm 0.00 \mathrm{abc}$ & $0.05 \pm 0.01 \mathrm{ab}$ & $0.06 \pm 0.01 \mathrm{a}$ & $0.05 \pm 0.01 \mathrm{ab}$ & \\
\hline & $\mathrm{BH} / \mathrm{CG}$ & $0.04 \pm 0.01 \mathrm{e}-\mathrm{h}$ & $0.04 \pm 0.01 \mathrm{e}-\mathrm{h}$ & $0.04 \pm 0.01 \mathrm{efg}$ & $0.05 \pm 0.01 \mathrm{ef}$ & $0.04 \pm 0.01 \mathrm{efg}$ & $0.09 \pm 0.01 \mathrm{~b}$ & $0.10 \pm 0.00 \mathrm{a}$ & \\
\hline & $\mathrm{ÇH} / \mathrm{GG}$ & $0.02 \pm 0.01 \mathrm{i}$ & $0.03 \pm 0.01 \mathrm{hi}$ & $0.04 \pm 0.01 \mathrm{f}-\mathrm{I}$ & $0.04 \pm 0.01 \mathrm{f}-\mathrm{I}$ & $0.03 \pm 0.01$ ghi & $0.05 \pm 0.01 \mathrm{ef}$ & $0.05 \pm 0.00 \mathrm{de}$ & $* * * \quad * * * * * *$ \\
\hline & SK/DM & $0.04 \pm 0.01 \mathrm{efg}$ & $0.05 \pm 0.00 \mathrm{de}$ & $0.05 \pm 0.01 \mathrm{de}$ & $0.06 \pm 0.00 \mathrm{~cd}$ & $0.05 \pm 0.01 \mathrm{ef}$ & $0.06 \pm 0.01 \mathrm{c}$ & $0.07 \pm 0.01 \mathrm{c}$ & \\
\hline
\end{tabular}

Ö: Özellik, M: Metot, MS: Muhafaza süresi, BH: Beton harman, CH: Cimen harman ve SK: Suni kurutma. Ortalama \pm SD şeklinde ifade edilmiştir. Kurutma yöntemleri ve depolama süreleri arasındaki farklılıklar farklı harflerle gösterilmiştir. Önem seviyeleri; *, **, *** ve "öd" $P<0.05,0.01,0.001$ ve "önemli değil"

P:Parameter, D: Drying, S: Storage periods, CG: Concrete ground, GG: Grass ground and DM: Drying machine. Values are expressed as mean \pm standart deviation. Different letters in columns for each different drying, mean significantly different values among storage time. Significant level; *, **, *** and "ns" mean significance at $P<0.05,0.01,0.001$ and "not significant", respectively, between drying and storage time. 
Doymuş yağ asitleri (DYA), tekli doymamış yağ asitleri (TDY), çoklu doymamış yağ asitleri (ÇDY), doymamış/doymuş yağ asitleri oranı (TDY+ÇDY/DYA), oleik/linoleik oranı (O/L), iyot değeri (ID), serbest yağ asitliği (SYA), ransimat değeri (RD) ve peroksit değeri (PD) Çizelge 3'de görülmektedir. Beklendiği gibi, TDY (\%84.15-84.46) ana yağ asidi grubu oluşturmuş, onu ÇDY (\%9.31-10.02) ve DYA (\%5.83-6.27) izlemiştir. Alaşalvar vd. (2010) benzer sonuçlar elde etmiş ve findıkların düşük oranda DYA (\%7.46-9.59), orta düzeyde ÇDY (\%3.92-13.86) ve yüksek miktarda ÇDY (\%78.10-87.26) içerdiğini bildirmiştir. Turan (2018a) ise benzer şekilde findıkların düşük oranda DYA (\%5.77), orta düzeyde ÇDY (\%10.15) ve yüksek düzeyde TDY (\%84.76) içerdiğini bildirmiştir. Ancak Amaral vd. (2006), TDY ana grup yağ asitlerini oluştururken DYA ve ÇDY yağ asitlerinin eşit seviyede olduğunu belirtmişlerdir. Kurutma yöntemlerinin toplam yağ asitleri ve yăg oksidasyonu üzerine etkisi istatistikî olarak önemli bulunmuştur $(P<0.001)$ ve veriler Çizelge 3'de verilmiştir. En yüksek DYA değeri $\mathrm{BH}(\% 6.27)$ metodunda kaydedilirken en düşük değer ise ÇH (\%5.82) kaydedilmiştir. Özdemir vd. (2002) "Tombul" ile Turan (2018b) ise Ordu Levant findıklarinda elde edilen verilerde olduğu gibi kurutma metotları arasındaki farklılık istatistikî olarak önemli bulunmuştur $(P<0.001$; Çizelge 3$)$. Ancak, cevizlerde ise günește ve firında kurutma yöntemlerinin palmitik (\%6.08-6.64) ve stearik asit (\%1.77-1.71) üzerine etkili olmadığ görülmüştür (Qu vd., 2016). Muhafaza süresi boyunca ise DYA değerinde bazı dönemlerde dalgalanma görülmekle birlikte artış görülmüştür (\%5.74-7.30; Çizelge 3). Ghirardello vd. (2013) ve Turan (2018a) ortam şartlarında muhafaza edilen findıklarda DYA değerinin yükseldiğini (\%7.698.51, \%5.63-6.14, sirasiyla), Belviso vd. (2017) ise kavurma sıcaklı̆̆1 ve çeşide göre farkllilı gösterdiğini bildirmiştir. Örneğin, Tonda Gentile Trilobata (TGT) çeşidinde kavurma sıcaklığının artışı ile DYA muhafaza süresince azalış $\left(170^{\circ} \mathrm{C}-\right.$ $20 \mathrm{dk} ; \% 9.73-9.32$ ), Ordu findıklarında ise artış (\%7.37-7.61) olduğu görülmüştür.

TDY temel olarak oleik (C18:1) yağ asidinden oluşmuş ve bunu palmitoleik (C16:1), eikosenoik
(C20:1), heptadesenoik (C17:1), ve nervonik (C24:01) yağ asitleri takip etmiş, kurutma yöntemleri arasında istatistiksel olarak önemli farklilık bulunmuş $(P<0.001)$ ve en yüksek TDY değeri SK (\%84.46), en düşük ise GG (\%84.15) metodunda kaydedilmiştir (Çizelge 3). Çalışmamızın aksine Turan (2018a) en yüksek TDY değerinin BH (\%85.03), ve en düşük değerin ise SK (\%84.38) metodunda olduğunu bildirmiştir. Özdemir vd. (2002) ise Tombul findık çeşidinde kurutma sıcaklığının artış ile oleik asit değerinin yükseldiğini $\left(35-50^{\circ} \mathrm{C}\right.$; $\% 81.0-83.3$, sirasiyla), Delgado vd. (2016) ise çeşitlere göre farklilık görünmekle birlikte kestanelerde kurutma süresinin artışı ile azaldığını (0-10 sa; \%36.2-32.3, sirasiyla), Delgado vd. (2017) ise kurutma yöntemlerine göre \%37.9529.9 arasında değiştiğini bildirmiştir. TDY değeri muhafaza süresince ise beklendiği gibi azalma göstererek \%84.46-81.36 aralığında seyretmiş (Çizelge 3) ve Belviso vd. (2017) tarafindan TGT ve Turan (2018a) Ordu Levant findıklarında elde edilen verilerle benzerlik göstermiştir. Ancak Delgado vd. (2017) ise kestanelerde depolama süresince kurutma yöntemlerine göre TDY değerinin farklı davranış gösterdiğini bildirmiştir. Genel olarak linoleik (C18:2) ve linolenik (C18:3) yağ asitlerinin ÇDY'nın en iyi temsilcisi olduğu (Turan 2018a) ve linoleik asit değerinin her zaman toplam yağ asitlerinin \%9'unun altında olduğu bildirilmiş (Ghirardello vd., 2013), ancak çalışmamızda Tombul çeşidinde böyle olmadığı (\%9.31-10.03) görülmüştür (Çizelge 3). Kurutma yöntemleri arasında, en yüksek ÇDY değeri ÇH (\%10.02), en düşük değer ise SK (\%9.31) metodunda kaydedilmiş, farklılık istatistikî olarak önemli bulunmuş ( $P<0.001$; Çizelge 3$)$ ve Delgado vd. (2017) ile benzerlik göstermiştir. Muhafaza süresince ise ÇDY değeri dalgalanma göstermekle birlikte genellikle artış göstermiştir (Çizelge 3). Belviso vd. (2017) benzer şekilde muhafaza süresince ÇDY değerinin kavrulmuş findıklarda artış gösterdiğini, Ghirardello vd. (2013) ise linoleik asit (C18:2) oranının ortam şartlarında 12 ay muhafaza süresince yükseldiğini (\%6.16-6.87), ancak linolenik asit (C18:3) değerinin azalış gösterdiğini (\%0.13-0.00) bildirmiştir. 
Çizelge 3 Kurutma yöntemlerinin 18 ay depolama süresince findığın toplam yağ asitleri ve yağ oksidasyonu üzerine etkileri

Table 3 Effect of drying methods on sum of fatty acids and oil oxidation of hazelnut during 18 months of storage periods

\begin{tabular}{|c|c|c|c|c|c|c|c|c|c|}
\hline \multirow[b]{2}{*}{$\mathrm{O} / P$} & \multirow[b]{2}{*}{$\begin{array}{l}\mathrm{M} / \\
D\end{array}$} & \multicolumn{7}{|c|}{ Muhafaza süreleri (ay)/Storage periods (months) } & \multirow{2}{*}{$\begin{array}{c}\text { Önemlilik/Sig } \\
\mathrm{M} / D \mathrm{MS} / \mathrm{S} \\
\mathrm{MxMS} / D x \\
S\end{array}$} \\
\hline & & 0 & 3 & 6 & 9 & 12 & 15 & 18 & \\
\hline \multirow{3}{*}{$\begin{array}{l}\text { DYA/ } \\
\text { SF } A(\%)\end{array}$} & $\mathrm{BH} / C G$ & $6.27 \pm 0.10 \mathrm{~d}-\mathrm{g}$ & $6.27 \pm 0.10 \mathrm{~d}-\mathrm{g}$ & $6.33 \pm 0.01 \mathrm{c}-\mathrm{f}$ & $6.32 \pm 0.02 \mathrm{c}-\mathrm{f}$ & $6.32 \pm 0.02 \mathrm{c}-\mathrm{f}$ & $7.32 \pm 0.03 \mathrm{a}$ & $7.30 \pm 0.01 \mathrm{a}$ & \multirow{3}{*}{$\begin{array}{c}* * * \quad * * * \\
* * *\end{array}$} \\
\hline & $\mathrm{ÇH} / G G$ & $5.82 \pm 0.10 \mathrm{~h}$ & $5.74 \pm 0.05 \mathrm{~h}$ & $5.77 \pm 0.06 \mathrm{~h}$ & $5.79 \pm 0.02 \mathrm{~h}$ & $5.79 \pm 0.01 \mathrm{~h}$ & $6.23 \pm 0.01 \mathrm{efg}$ & $6.18 \pm 0.02 \mathrm{fg}$ & \\
\hline & $\mathrm{SK} / D M$ & $6.23 \pm 0.21 \mathrm{efg}$ & $6.10 \pm 0.05 \mathrm{~g}$ & $6.81 \pm 0.47 \mathrm{~b}$ & $6.42 \pm 0.03 \mathrm{cde}$ & $6.40 \pm 0.03 \mathrm{cde}$ & $6.49 \pm 0.01 \mathrm{c}$ & $6.46 \pm 0.01 \mathrm{~cd}$ & \\
\hline \multirow{3}{*}{$\begin{array}{l}\text { TDY/ } \\
\text { MUF } A(\%)\end{array}$} & $\mathrm{BH} / \mathrm{CG}$ & $84.38 \pm 0.02 \mathrm{ab}$ & $84.35 \pm 0.06 \mathrm{ab}$ & $84.23 \pm 0.01 \mathrm{abc}$ & $84.22 \pm 0.02 \mathrm{abc}$ & $84.22 \pm 0.03 \mathrm{abc}$ & $82.24 \pm 0.03 \mathrm{e}$ & $82.26 \pm 0.02 \mathrm{e}$ & \multirow{3}{*}{$\begin{array}{c}* * * \quad * * * \\
* * *\end{array}$} \\
\hline & $\mathrm{ÇH} / G G$ & $84.15 \pm 0.09 \mathrm{bc}$ & $84.14 \pm 0.02 \mathrm{bc}$ & $84.14 \pm 0.04 \mathrm{bc}$ & $84.01 \pm 0.02 \mathrm{c}$ & $84.00 \pm 0.03 \mathrm{c}$ & $82.33 \pm 0.02 \mathrm{e}$ & $82.33 \pm 0.01 \mathrm{e}$ & \\
\hline & $\mathrm{SK} / D M$ & $84.46 \pm 0.17 \mathrm{a}$ & $84.27 \pm 0.05 \mathrm{ab}$ & $82.96 \pm 0.66 \mathrm{~d}$ & $82.74 \pm 0.04 \mathrm{~d}$ & $82.72 \pm 0.01 \mathrm{~d}$ & $81.37 \pm 0.05 \mathrm{f}$ & $81.36 \pm 0.02 \mathrm{f}$ & \\
\hline \multirow{3}{*}{$\begin{array}{l}\text { ÇDY/ } \\
\text { PUFA (\%) }\end{array}$} & $\mathrm{BH} / C G$ & $9.41 \pm 0.17 \mathrm{f}$ & $9.41 \pm 0.17 \mathrm{f}$ & $9.44 \pm 0.01 \mathrm{f}$ & $9.46 \pm 0.02 \mathrm{f}$ & $9.46 \pm 0.02 \mathrm{f}$ & $10.45 \pm 0.01 \mathrm{~d}$ & $10.44 \pm 0.02 \mathrm{~d}$ & \multirow{3}{*}{$\begin{array}{c}* * * \quad * * * \\
* * *\end{array}$} \\
\hline & $\mathrm{ÇH} / G G$ & $10.02 \pm 0.00 \mathrm{e}$ & $10.12 \pm 0.04 \mathrm{de}$ & $10.09 \pm 0.02 \mathrm{e}$ & $10.20 \pm 0.01 \mathrm{de}$ & $10.21 \pm 0.03 \mathrm{de}$ & $11.45 \pm 0.03 \mathrm{~b}$ & $11.49 \pm 0.02 \mathrm{~b}$ & \\
\hline & $\mathrm{SK} / D M$ & $9.31 \pm 0.05 \mathrm{f}$ & $9.64 \pm 0.10 \mathrm{f}$ & $10.23 \pm 0.88 \mathrm{de}$ & $10.84 \pm 0.03 c$ & $10.88 \pm 0.03 \mathrm{c}$ & $12.14 \pm 0.05 \mathrm{a}$ & $12.18 \pm 0.01 \mathrm{a}$ & \\
\hline \multirow{3}{*}{$\begin{array}{l}\text { TDY+ÇDY: } \\
\text { DYA/MUFA+ } \\
\text { PUFA: SFA }\end{array}$} & $\mathrm{BH} / C G$ & $14.96 \pm 0.26 \mathrm{~b}-\mathrm{e}$ & $14.96 \pm 0.26 \mathrm{~b}-\mathrm{e}$ & $14.80 \pm 0.02 \mathrm{c}-\mathrm{f}$ & $14.82 \pm 0.04 \mathrm{c}-\mathrm{f}$ & $14.82 \pm 0.04 \mathrm{c}-\mathrm{f}$ & $12.67 \pm 0.05 \mathrm{~h}$ & $12.69 \pm 0.01 \mathrm{~h}$ & \multirow{3}{*}{$\begin{array}{c}* * * \quad * * * \\
* * *\end{array}$} \\
\hline & $\mathrm{C} \mathrm{H} / \mathrm{GG}$ & $16.17 \pm 0.29 \mathrm{a}$ & $16.42 \pm 0.14 a$ & $16.34 \pm 0.17 \mathrm{a}$ & $16.28 \pm 0.05 a$ & $16.26 \pm 0.03 \mathrm{a}$ & $15.06 \pm 0.01 \mathrm{bcd}$ & $15.18 \pm 0.05 b c$ & \\
\hline & $\mathrm{SK} / D M$ & $15.07 \pm 0.54 \mathrm{bcd}$ & $15.40 \pm 0.14 \mathrm{~b}$ & $13.73 \pm 1.00 \mathrm{~g}$ & $14.57 \pm 0.07 \mathrm{ef}$ & $14.63 \pm 0.09 \mathrm{def}$ & $14.40 \pm 0.01 \mathrm{f}$ & $14.48 \pm 0.02 \mathrm{f}$ & \\
\hline \multirow{3}{*}{$\mathrm{O} / \mathrm{L}$} & $\mathrm{BH} / C G$ & $9.04 \pm 0.16 \mathrm{ab}$ & $9.03 \pm 0.17 \mathrm{ab}$ & $8.99 \pm 0.01 \mathrm{ab}$ & $8.97 \pm 0.02 \mathrm{ab}$ & $8.97 \pm 0.03 \mathrm{ab}$ & $7.91 \pm 0.00 \mathrm{~d}$ & $7.92 \pm 0.01 \mathrm{~d}$ & \multirow{3}{*}{$\begin{array}{c}* * * \quad * * * \\
* * *\end{array}$} \\
\hline & $\mathrm{Ç} / \mathrm{GG}$ & $8.47 \pm 0.06 \mathrm{c}$ & $8.39 \pm 0.03 c$ & $8.40 \pm 0.01 \mathrm{c}$ & $8.28 \pm 0.01 \mathrm{c}$ & $8.28 \pm 0.03 c$ & $7.24 \pm 0.02 \mathrm{e}$ & $7.20 \pm 0.01 \mathrm{e}$ & \\
\hline & $\mathrm{SK} / D M$ & $9.16 \pm 0.03 \mathrm{a}$ & $8.83 \pm 0.08 \mathrm{~b}$ & $8.22 \pm 0.74 \mathrm{c}$ & $7.69 \pm 0.02 \mathrm{~d}$ & $7.65 \pm 0.02 \mathrm{~d}$ & $6.73 \pm 0.03 \mathrm{f}$ & $6.70 \pm 0.00 \mathrm{f}$ & \\
\hline \multirow{3}{*}{ ID $/ I V$} & $\mathrm{BH} / C G$ & $92.98 \pm 0.30 \mathrm{c}$ & $92.96 \pm 0.26 \mathrm{c}$ & $92.90 \pm 0.01 \mathrm{c}$ & $92.92 \pm 0.02 c$ & $92.91 \pm 0.02 \mathrm{c}$ & $92.85 \pm 0.01 \mathrm{c}$ & $92.85 \pm 0.02 \mathrm{c}$ & \multirow{3}{*}{$\begin{array}{c}* * * \quad * * * \\
* * *\end{array}$} \\
\hline & $\mathrm{CH} / G G$ & $93.89 \pm 0.11 \mathrm{~b}$ & $94.06 \pm 0.06 \mathrm{~b}$ & $93.99 \pm 0.08 \mathrm{~b}$ & $94.08 \pm 0.02 \mathrm{~b}$ & $94.10 \pm 0.03 \mathrm{~b}$ & $94.80 \pm 0.03 \mathrm{a}$ & $94.89 \pm 0.02 \mathrm{a}$ & \\
\hline & $\mathrm{SK} / D M$ & $92.85 \pm 0.23 \mathrm{c}$ & $93.27 \pm 0.14 c$ & $93.16 \pm 1.16 c$ & $94.05 \pm 0.05 \mathrm{~b}$ & $94.11 \pm 0.05 b$ & $95.16 \pm 0.04 \mathrm{a}$ & $95.23 \pm 0.02 \mathrm{a}$ & \\
\hline \multirow{3}{*}{$\begin{array}{l}\text { SYA/ } \\
\text { FF } A \\
\text { (\%, oleic acid) }\end{array}$} & $\mathrm{BH} / C G$ & $0.24 \pm 0.02 \mathrm{kl}$ & $0.28 \pm 0.01 \mathrm{ij}$ & $0.36 \pm 0.00 \mathrm{fg}$ & $0.42 \pm 0.02 \mathrm{e}$ & $0.99 \pm 0.04 \mathrm{a}$ & $0.89 \pm 0.01 \mathrm{~b}$ & $0.61 \pm 0.02 \mathrm{c}$ & \multirow{3}{*}{$\begin{array}{c}* * * \quad * * * \\
* * *\end{array}$} \\
\hline & $\mathrm{C} \mathrm{H} / G G$ & $0.28 \pm 0.02 \mathrm{ij}$ & $0.22 \pm 0.011$ & $0.33 \pm 0.00 \mathrm{gh}$ & $0.41 \pm 0.02 \mathrm{e}$ & $0.60 \pm 0.02 \mathrm{c}$ & $0.60 \pm 0.04 \mathrm{c}$ & $0.52 \pm 0.01 \mathrm{~d}$ & \\
\hline & $\mathrm{SK} / D M$ & $0.15 \pm 0.02 \mathrm{~m}$ & $0.31 \pm 0.02 \mathrm{hi}$ & $0.26 \pm 0.01 \mathrm{jk}$ & $0.42 \pm 0.01 \mathrm{e}$ & $0.37 \pm 0.02 \mathrm{f}$ & $0.33 \pm 0.01 \mathrm{gh}$ & $0.55 \pm 0.02 \mathrm{~d}$ & \\
\hline \multirow{3}{*}{$\begin{array}{l}\mathrm{RD}(\mathrm{sa}) / \\
\mathrm{RV}(\not)\end{array}$} & $\mathrm{BH} / C G$ & $5.88 \pm 0.04 a$ & $4.06 \pm 0.03 \mathrm{cde}$ & $3.59 \pm 0.22 \mathrm{f}$ & $4.31 \pm 0.25 \mathrm{~cd}$ & $1.88 \pm 0.10 \mathrm{i}$ & $2.00 \pm 0.19 \mathrm{hi}$ & $3.85 \pm 0.06 \mathrm{ef}$ & \multirow{3}{*}{$\begin{array}{c}* * * \quad * * * \\
* * *\end{array}$} \\
\hline & $\mathrm{C} \mathrm{H} / G G$ & $5.34 \pm 0.14 \mathrm{~b}$ & $4.30 \pm 0.13 \mathrm{~cd}$ & $4.11 \pm 0.16 \mathrm{cde}$ & $4.36 \pm 0.06 \mathrm{c}$ & $2.84 \pm 0.27 \mathrm{~g}$ & $2.28 \pm 0.12 \mathrm{~h}$ & $4.05 \pm 0.21 \mathrm{cde}$ & \\
\hline & $\mathrm{SK} / D M$ & $5.62 \pm 0.14 \mathrm{ab}$ & $5.37 \pm 0.06 \mathrm{~b}$ & $4.22 \pm 0.44 \mathrm{cde}$ & $4.21 \pm 0.36 \mathrm{cde}$ & $4.27 \pm 0.49 \mathrm{~cd}$ & $3.95 \pm 0.20 \mathrm{def}$ & $3.99 \pm 0.31 \mathrm{de}$ & \\
\hline \multirow{3}{*}{$\begin{array}{l}\mathrm{PD} / \\
\mathrm{PV} \\
\left(\mathrm{meqO}_{2 /} / \mathrm{kg}\right)\end{array}$} & $\mathrm{BH} / C G$ & $0.00 \pm 0.00 j$ & $0.46 \pm 0.03 a$ & $0.17 \pm 0.02 \mathrm{ef}$ & $0.18 \pm 0.02 \mathrm{def}$ & $0.44 \pm 0.04 \mathrm{a}$ & $0.15 \pm 0.04 \mathrm{efg}$ & $0.03 \pm 0.05 \mathrm{ij}$ & \multirow{3}{*}{$\begin{array}{c}* * \\
* * * * \\
* * *\end{array}$} \\
\hline & $\mathrm{C} \mathrm{H} / G G$ & $0.06 \pm 0.10 \mathrm{hi}$ & $0.18 \pm 0.04 \mathrm{def}$ & $0.08 \pm 0.02 \mathrm{hi}$ & $0.20 \pm 0.01 \mathrm{cde}$ & $0.23 \pm 0.02 \mathrm{~cd}$ & $0.10 \pm 0.02 \mathrm{fg}$ & $0.34 \pm 0.03 b$ & \\
\hline & $\mathrm{SK} / D M$ & $0.00 \pm 0.00 \mathrm{j}$ & $0.35 \pm 0.04 \mathrm{~b}$ & $0.25 \pm 0.01 \mathrm{c}$ & $0.11 \pm 0.02 \mathrm{gh}$ & $0.13 \pm 0.01 \mathrm{fg}$ & $0.25 \pm 0.02 \mathrm{c}$ & $0.24 \pm 0.02 \mathrm{c}$ & \\
\hline \multicolumn{10}{|c|}{$\begin{array}{l}\text { Ö: Özellik, M: Metot, MS: Muhafaza süresi, BH: Beton harman, ÇH: Çimen harman ve SK: Suni kurutma. Ortalama } \pm \text { SD şeklinde ifade } \\
\text { edilmiştir. Kurutma yöntemleri ve depolama süreleri arasındaki farkllliklar farklı harflerle gösterilmiştir. Önem seviyeleri; *, **, *** ve "öd" } \\
P<0.05,0.01,0.001 \text { ve "önemli değil" } \\
\text { P:Parameter, D: Drying, S: Storage periods CG: Concrete ground, GG: Grass ground and DM: Drying macbine. Values are expressed as mean } \pm \text { standart } \\
\text { deviation. Different letters in columns for each different drying, mean significantly different values among storage time. Significant level; *, **, *** and "ns" mean } \\
\text { significance at P }<0.05,0.01,0.001 \text { and "not significant", respectively, between drying and storage time. }\end{array}$} \\
\hline
\end{tabular}

Qu vd. (2016) and Juhaimi vd. (2018) tarafindan bulunan sonuçların aksine, çalışmamızda doymamış/doymuş (TDY+ÇDY/DYA) yă̆ asitleri üzerine kurutma yöntemlerinin etkisi istatistiksel olarak önemli bulunmuş $(P<0.001$; Çizelge 3), TDY+ÇDY/DYA değeri \%14.9616.17 aralı̆ı̆ında değişmiş ve en yüksek değer ÇH, en düşük değer ise $\mathrm{BH}$ metodunda kaydedilmiştir. TDY+ÇDY/DYA oranı findıklarda raf ömrünü tahmin etmek için kullanılmakta ve oranın düşük olması raf ömrünün yüksek olduğunu göstermektedir. Bu oranın "Tombul” çeşidinde \%17.12, "Çakılldak" çeşidinde \%13.82 ve raf ömrü en uzun "Cavcava" çeşidinde ise \%7.84 olduğu bilinmektedir (Özdemir vd., 1998). Buradan da, $\mathrm{ÇH}$ metodunun muhafaza için en uygun yöntem olmadiğ1 söylenebilir. Muhafaza süresince TDY+ÇDY/DYA değeri bazı dönemlerde küçük dalgalanmalar göstermekle Ghirardello vd. (2013), Belviso vd. (2017) ve Turan (2018a) çalışmalarına benzer şekilde muhafaza süresince azalma göstermiştir.

\section{Yağ oksidasyonu}

Fındık yağlarında oleik (C18:1) ve linoleik (C18:2) doymamış yağ asitleri yüksek oranda bulunmakta ve bu nedenle de oksidasyona karşı hassas oldukları bilinmektedir (Alaşalvar vd., 2010; Turan 2018b). Ayrica oleik/linoleik asit oran1 $(\mathrm{O} / \mathrm{L})$ findıkların iç kalitesini değerlendirmede kullanılan önemli özelliklerden birisidir ve linoleik asit, oleik aside oranla oksidasyona karşı daha 
duyarlidir ( $\mathrm{Qu}$ vd., 2016). Bu nedenle O/L oranının yüksek olması oksidasyona karşı daha dayanıklı olduğunun göstergesidir (Belviso vd., 2017; Turan 2018a). Çalışmamızda kurutma yöntemlerinin $\mathrm{O} / \mathrm{L}$ oranı üzerine etkisi istatistiksel olarak önemli bulunmuş $(P<0.001$; Çizelge 3) en yüksek değer SK (9.16), en düşük değer ise ÇH (8.47) metodunda kaydedilmiştir. Cevizlerde ise Qu vd. (2016) firnda kurutulan örneklerde oleik asit (C18:1) değerinde önemli oranda artış (\%12.52-21.11, sırasıyla) olduğunu, linoleik asit (C18:2) değerinde azalma (\%70.4161.05) olduğunu ve bizim bulguların aksine bu değerlerin güneşte kurutmadan daha yüksek olduğu bildirmiştir. Muhafaza süresince ise kurutma yöntemlerinin tamamında genel olarak Belviso vd. (2017) benzer șekilde azalma kaydedilmiştir. İyot değeri (ID) yağların doymamışlığının bir ölçüsü olarak bilinmekte ve absorbe edilen iyot miktar1 olarak ifade edilmektedir (Ajith vd., 2015; Belviso vd., 2017; Turan 2018a). Ayrıca İD değerinin yüksek olması yağ oksidasyonuna karşı daha hassas ve kararsız olduğunun göstergesi olarak değerlendirilmektedir. Diğer yandan da doymamış yağ asitleri oranı düşük olan findıklarda ID değerinin de daha düşük olduğu bilinmektedir. Bunlara ilave olarak, Özdemir vd. (2002) ID değerinin Tombul çeşidinde kurutma sıcaklığının artışına paralel artış gösterdiğini bildirmiştir (sırasıyla, $35-50^{\circ} \mathrm{C} ; 87.7-89.0$ ). Çalışmamızda ise, Turan (2018a)'e benzer şekilde kurutma yöntemlerinin İD değeri üzerine etkisi istatistiksel olarak önemli bulunmuş $(P<0.001$; Çizelge 3$)$ ve en düşük değer SK (92.85), en yüksek değer ise ÇH (93.89) metodunda görülmüştür. Muhafaza süresince ise, İD değerinde Belviso vd. (2017) tarafindan yürütülen çalışmaya benzer şekilde artış görülmüştür.

Serbest yağ asitliği (SYA) kalite kaybının ilk göstergesi olarak kabul edilmekte ve SYA $\geq \% 1$ değerinin üzerine çıkması bozulma göstergesi olarak bilinmektedir (Turan ve İslam, 2018). Çalışmamızda, SYA değeri kurutma yöntemlerine göre farkl1lık göstermiş $(P<0.001$; Çizelge 3$)$ ve en yüksek değer ÇH $(\% 0.28$, oleik asit), en düşük değer ise SK (\%0.15, oleik asit) metodunda kaydedilmiştir. Benzer sonuçlar Fu vd. (2016) ve
Qu vd. (2016) tarafindan da tespit edilmiş ve güneş 1şığı altında uzun süre kurutulan cevizlerde yağ moleküllerinin SYA salgıladıkları ve bu nedenle değerinin yükseldiği bildirilmişlerdir. Ancak Kashaninejad vd. (2003) kurutma yöntemlerinin antepfıstıklarında SYA değerini etkilemediğini bildirmiştir. Muhafaza süresi boyunca ise SYA değeri yükselerek \%0.16-0.99 arasında kaydedilmiş ve çalışmamıza benzer şekilde davranış gösteren bazı çalışmalarda da aynı yönde değişim olduğu görülmüştür (Turan ve İslam, 2016; Koç Güler vd., 2017; Turan, 2018a; Turan, 2019). Muhafaza süresi sonunda ise en yüksek SYA değeri BH (\%0.61, oleik asit) metodunda kaydedilmiş ve bu sonuç yağların bozulmasında eşik olarak görülen ( $\% 0.7$, oleik asit) sınır değerin altında gerçekleşmiştir. Ancak BH metodunda 12 ve 15 . aylarda (\%0.99-0.89 oleik asit, sırasiyla) eşik değerin üzerinde seyretmiştir. $\mathrm{Bu}$ nedenle, ortam şartlarında jüt çuvalda muhafaza edilen kabuklu Tombul çeșidinin SYA değeri bakımından 18 ay muhafaza edilebileceği (ÇH ve SK metotlarında) görülmüştür. Kurutma yöntemlerinin $\mathrm{RD}$ üzerine etkisi istatistiksel olarak önemli bulunmuş ( $P$ $<0.001$; Çizelge 3) ve en yüksek değer SK ve $\mathrm{BH}$ (5.62-5.88 sa, sirasiyla) metotlarinda kaydedilmiştir ( $P<0.001$; Çizelge 3$)$. Turan ve İslam (2016) güneşte kurutma yöntemlerinde daha düşük RD tespit ettiklerini, bu nedenle suni kurutma yöntemlerinin kısa sürede kurutma ve yüksek RD değeri nedeniyle tercih edilmesi gerektiğini bildirmiştir. Ancak çalışmamızda güneşte kurutma ve suni kurutma yöntemleri arasında böyle bir farklılık tespit edilmemiştir. Muhafaza süresi boyunca ise beklendiği ve başka çalışmalarda olduğu gibi (Turan ve İslam, 2018; Turan, 2019) RD azalmış ve bu azalma 5.88-1.88 sa aralığında gerçekleşmiştir $(P<0.001$; Çizelge 3$)$. 18 ay muhafaza süresi boyunca ise en düşük değerler genel olarak $\mathrm{BH}$ ve $\mathrm{C} H$ metotlarında gerçekleşmiştir.

Peroksit değeri (PD) findık sanayisi tarafindan depolanacak ürünlerde kullanılan önemli özelliklerdendir (Ghirardello vd., 2013; Koç Güler vd., 2017; Turan, 2018b) ve ayrica PD cevizlerde yă oksidasyonunun en önemli göstergesi olarak kabul edilmektedir ( $F u$ vd., 
2016). Çalışmamızda, kurutma yöntemlerinin PD değeri üzerine etkisi istatistiksel olarak önemli bulunmuştur ( $P<0.01$; Çizelge 3 ), en düşük değerler genel olarak SK ve en yüksek değerler ise $\mathrm{BH}$ ve ÇH metotlarında kaydedilmiştir. Muhafaza süresince ise PD değeri genelde dalgalanma göstermekle birlikte artı̧̧ göstermiş $(P<0.001$; Çizelge 3) ve bu değişim bir zirve değere ulaştıktan sonra benzer çalsşmalarda olduğu gibi (Koç Güler vd., 2017; Belviso vd., 2017; Turan 2018a) düşüş şeklinde gerçekleşmiştir. Bu durumun ise, muhafaza sirasinda PD'nin ikincil oksidasyon ürünlerine dönüşmesinden kaynaklandığ1 bilinmektedir (Turan, 2018a; Turan, 2019). Ancak başka çalışmalarda ise PD değerinin muhafaza süresi boyunca artış gösterdiği görülmüştür (Ghirardello vd., 2013; Raisi vd., 2015; Turan, 2019). Tespit edilen bu farklılıklar çeşit, kurutma yöntemi ve muhafaza koşulları gibi bazı faktörlerin bir veya birkaçının etkileşiminden kaynaklanmış olabilir (Amaral vd., 2006; Alaşalvar vd., 2010; Turan 2018a; Turan, 2019). Bu faktörlerin yanı sıra, findıklarda farklı kurutma yöntemleri farklı zaman-sicaklık profilleri oluşturabildiği ve bu yüzden her süreçte farklı kimyasal reaksiyonun oluşabileceği öngörülmektedir. Kimyasal reaksiyonların bazılarında ise, findığın içeriğini oluşturan bileşenlerle diğer kimyasallar reaksiyona girebilir ve bu değişimler analizlerde ölçülemeyebilir (Özilgen, 2014; Turan, 2019).

\section{SONUÇ}

Bu çalışma suni ve doğal kurutma yöntemlerinin uzun dönem depolama süresince "Tombul" findık çeşidinin yağ asitleri kompozisyonu ve yağ oksidayonu üzerine etkisi konusunda yapilan ilk çalışmadır. Çalışma sonucunda kurutma yöntemleri ve depolamanın yağ asitleri kompozisyonu ve yağ oksidasyon üzerine etkisi yöntemlere göre genel olarak farklilık göstermiştir. Çalışma sonucunda SK ortamında $\mathrm{BH}$ ve $\mathrm{C} H$ ortamlarına göre daha düşük SYA, PD ve ID tespit edilmiştir. Bu yüzden SK ortam1 "Tombul" fındık çeşidinin kurutulması için tavsiye edilebilir yöntem olarak öne çıkmıştır.

\section{TEŞEKKÜR}

Bu çalışma Ordu Üniversitesi Bilimsel Araştırma Projeleri Koordinasyon Birimi (ODUBAPTF1332), Altaş Yağ Sanayi (Ordu, Turkey) ve Gürsoy Tarımsal Ürünler Gıda Sanayi A.Ş. (Ordu, Turkey) tarafından desteklenmiştir. İstatistiksel analizler için Dr. Öğr. Üyesi Fatih ÖNER'e teşekkür ederiz. Bu çalışma Ali TURAN'in doktora çalışmasının bir kısmından oluşmaktadır.

\section{KAYNAKLAR}

Ajith, S., Pramod, S., Kumari, C.P., Potty, V.P. (2015). Effect of storage temperatures and humidity on proximate composition, peroxide value and iodine of raw cashew nuts. J Food Sci Technol, 52: 4631-4636 doi: 10.1007/s13197-0141476-6.

Alaşalvar, C., Pelvan, E., Topal, B. (2010). Effect of roasting oil and fatty acid composition of Turkish hazelnut varieties (Corylus avellana L.). Int J Food Sci. Nutr, 61: 630-642 doi: 10.1021/f101039f.

Amaral, J.S., Casal, S., Citová, I., Santos, A., Seabra, R.M., Oliveira, B.P.P. (2006). Characterization of several hazelnut (Corylus avellana L.) cultivars based in chemical, fatty acid and sterol composition. Eur Food Res Technol, 222: 274-280 doi: 10.1007/s00217-005-0068.

AOCS (2004). Official Methods and Recommended Practices of the American Oil Chemist's Society, 5th ed. American Oil Chemist Society, USA.

AOAC (2000). Official Methods of Analysis of AOAC International 17th ed. 40,1-3.

Başaran, P. (2010). Antifungal effect of acids and surface active compounds for postharvest control of Aspergillus paraticus growth on hazelnut. J Food Process and Preserv, 35: 236-246 doi: 10.1111/j.1745-4549.2009.00442.x.

Belviso, S., Bell, B.D., Giacosa, S., Bertolino, M., Ghirardello, D., Giordano, M., Rolle, L., Gerbi, V., Zeppa, G. (2017). Chemical, mechanical and sensory monitoring of hot air and infrared roasted hazelnuts (Corylus avellana L.) during nine months of storage. Food Chem, 217: 398-408 doi: 10.1016/.2016.08.103. 
Delgado, T., Pereira, J.A., Ramalhosa, E., Casal, S. (2016). Effect of hot air convective drying on the fatty acid and vitamin $\mathrm{E}$ composition of chestnut (Castanea sativa Mill.) slices. Eur Food Res Technol, 242: 1299-1306 doi: 10.1007/s00217-015-26335.

Delgado, T., Pereira, J.A., Ramalhosa, E., Casal, S. (2017). Comparison of different drying methods on the chemical and sensory properties of chestnut (Castanea sativa M.) slices. Eur Food Res Technol, 243: 1957-1971 doi: 10.1007/s00217017-2902-6.

Ficarra, A., Lo Fiego, D.P., Minelli, G., Antonelli, A. (2010). Ultra fast analysis of subcutaneous pork fat. Food Chem, 121: 809-814 doi: 10.1016.2010.01.003.

Fu, M., Qu, Q., Yang, X., Zhang, X. (2016). Effect of intermittent oven drying on lipid oxidation, fatty acids composition and antioxidant activities of walnut. LWT-Food Sci Technol, 65: 1126-1132 doi: 10.1016.2015.10.002.

Ghirardello, D., Contessa, C., Valentini, N., Zeppa, G., Rolle, R., Gerbi, V., Botta, R. (2013). Effect of storage condition on chemical and physical characteristics of hazelnut (Corylus avellana L.). Postharvest Biol and Technol, 81: 37-43 doi: 10.1016.2013.02.014.

Hashempour, A., Ghazvini, R.F., Bakhshi, D, Sanam, S.A. (2010) Fatty acids composition and pigments changing of virgin olive oil (Olea europea L.) in five cultivars grown in Iran. Aust J Crop Sci 4:258-263.

Janowicz, M., Lenart, A (2018). The impact of high pressure and drying processing on internal scructure and quality of fruit. Eur Food Res Technol, 244:1329-1340 doi: 10.1007/s00217- 018-3047-y.

Juhaimi, F.A., Özcan, M.M., Uslu, N., Ghafoor, K. (2018). The effect of drying temperatures on antioxidant activity, phenolic compounds, fatty acid composition and tocopherol contents in citrus and oils. Eur Food Res Technol, 55: 190-197 doi: 10.1007/s13197-017-2895-y.

Kashaninejad, M., Tabil, L.G., Mortazavi, A., Safeordi, A. (2003). Effect of drying methods on quality of pistachio nuts. Dry Technol, 21: 821-838 doi: 10.1081/DRT-120021688.

Kaveh, M., Gilandeh, Y.A., Chayjan, R.A., Taghinezhad, E., Mohammadigol, R. (2018). Mas transfer, physical, and mechanical characterictics of terebinth fruit (Pistacia atlantica L.) under convective infrared microwave drying. Heat Mass Transf, 54: 1879-1899 doi: 10.1007/s00231-0182287-5.

Kermani, A.M., Khashehchi, M., Kouravand, S., Sadeghi, A. (2017). Effect of intermittent microwave drying on quality characteristics of pistachio nuts. Dry Technol, 35: 1108-1116 doi: 10.1016. 2008.01.003.

Koç Güler, S., Bostan, S.Z., Con, A.Z. (2017). Effects of gamma irradiation on chemical and sensory characteristics of natural hazelnut kernels. Postharvest Biol Technol, 123: 12-21 doi: 10.1016.2016.08.007.

Köksal, A.İ. (2018). Türk findık cessitleri. Karadeniz findık ve Mamulleri İhracatçılar Birliği-İstanbul Findık ve Mamulleri İhracatçılar Birliği, Ankara, 182s.

Köse, Y.E. (2018). Matematiksel modellemenin kurutma teknolojisinde kullanım olanakları. Int $J$ Sci Technol Res, 4(6): 1-8.

Özay, G., Seyhan, F., Pembeci, C., Saklar, S., Yilmaz, A. (2008). Factors influencing fungal and aflatoxin levels in Turkish hazelnuts (Corylus avellana L.) during growth, harvest, drying and storage: A 3-year study. Food Addict Contam, 25: 209-218 doi: 10.1080/02652030701711016.

Özdemir, M., Özay, G., Seyhan, F.G. (1998). Hasattan ambalaja findik işlemenin kritik kontrol noktalarnda tehlike analizi. Marmara Araştırma Merkezi. Gebze-Kocaeli, Türkiye, 39s.

Özdemir, M., Yıldız, M., Gürcan, T.Ş. (2002). Effect of artificial trying air temperature on stability of the major Turkish hazelnut variety Tombul. GID A, 27: 35-39.

Özilgen, S. (2014). Cooking as a chemical reaction: culinary science with experiments. CRC Press, USA, $283 \mathrm{p}$. 
Qu, Q., Yang, X., Fu, M., Chen, Q., Zhang, X., He, Z., Qiao, X. (2016). Effects of three conventional drying methods on the lipid oxidation, fatty acids composition, and antioxidant activities of walnut (Juglans regia L.). Dry Technol, 34: 822-829 doi: 10.1080/07373937.2015.1081931.

Raisi, M., Ghorbani, M., Mahoonak, A.S., Kashaninejad, M. (2015). Effect of storage atmosphere and temperature on the oxidative stability of almond kernels during long-term storage. J Stored Prod Res, 62: 16-21 doi: 10.1016/j.jspr.2015.03.004.

Turan, A., İslam, A. (2016). Changes during storage period and the drying methods in the Çakıldak hazelnut cultivar. Ordu Univ J Sci Tech, 6: 272-285.

Turan, A., İslam, A. (2018). Effect of drying methods on some chemical characteristics of hazelnuts (Corylus avellana L.) during storage. J Inst Sci Tech, 8(3): 11-19 doi: 10.21597/jist.458541.

Turan, A. (2018a). Effect of drying methods on fatty acid profile and oil oxidation of hazelnut oil during storage. Eur Food Res Technol, 244(12): 2181-2190 doi: 10.1007/s00217-018-3128-y.

Turan, A. (2018b). Effect of drying methods on nut quality of hazelnuts (Corylus avellana L.). J Food Sci Technol, 55(11): 4554-4565 doi: 10.1007/s13197-018-3391-8.
Turan, A. (2019). Effect of drying on the chemical composition of Çakıldak (cv) hazelnuts during storage. Grasas Aceites, 70(1), e296 doi: 10.3989/gya.0693181.

Tüfekçi, F., Karataş, Ş. (2018). Determination of geographical origin Turkish hazelnuts according to fatty acid composition. Food Sci Nutr, 00: 1-6 doi: 10.1002/fsn3.595.

Velasco, J., Anderson, M.L., Skibsted, L.H. (2004). Evaluation of oxidative stability of vegetable oils by monitoring the tendency to radical formation. A comparison of electron spins resonance spectroscopy with the rancimat method and differential scanning calorimetry. Food Chem, 85: 623-632 doi: 10.1016.2003.07.020.

WAA (2004). Operating Manual Novasina. AW Sprint TH 500 Water Activity Analyzers.

Wang, W., Jung, J., McGorrin, R.J., Traber, M.G., Leonard, G.C., Zhao, Y. (2018). Investigation of drying conditions on bioactive compounds, lipid oxidation, and enzyme activity of Oregon hazelnuts (Corylus avellana L.). LWT-Food Sci Technol, 90: 526-534 doi: 10.1016/j.lwt. 2018.01.002.

Zhang, L., Wang, Z., Shi, G., Yang, H., Wang, X., Zhao, H., Zhao, S. (2018). Effects of drying methods on the nutritional aspects, flavor, and processing properties of Chinese chestnuts. J Food Sci Technol, doi: 10.1007/s13197-018-3227-6. 